\title{
Kutseõpetajate professionaalse mälu roll õpilastega seotud muutuste kogemisel
}

\author{
Meidi Sirk $^{\mathrm{a} 1}$, Reeli Liivik ${ }^{\mathrm{a}}$, Meril Ümarik ${ }^{\mathrm{a}}$, Krista Loogma ${ }^{\mathrm{a}}$ \\ ${ }^{a}$ Tallinna Ülikooli haridusteaduste instituut
}

\begin{abstract}
Annotatsioon
Kutseõpetajate professionaalsust mõjutavad oluliselt õpilaskonna muutused, millega on kaasnenud uued nõudmised tööle. Varasemates uurimustes on rõhutatud, et muutuste kogemisele avaldab mõju professionaalne mälu, mis sisaldab ametialaseid mälestusi ja sündmusi, kujundades nende kaudu professionaalseid teadmisi ja tööalaseid tavasid. Käsitledes professionaalset mälu kui ühte kutseõpetajate professionaalsuse karakteristikut, oleme seadnud uurimuse eesmärgiks selgitada kutseõpetajate kogetud muutusi õpilaskonnas, tuginedes professionaalse mälu kontseptsioonile. Artikkel põhineb kombineeritud uurimisviisil, kus andmeid koguti kvantitatiivse küsitluse ja kvalitatiivse poolstruktureeritud intervjuudega. Uurimistulemustest ilmneb, et lühema staažiga ja nooremad kutseõpetajad kogevad muutusi õpilaskonnas positiivsemalt kui pikema staažiga ja vanemad kutseõpetajad. Lisaks mõjutab muutuste kogemist töö kontekst. Õpilaskonna muutustele antud tähendused sõltuvad ühiskondlikest ja hariduspoliitilistest sündmustest, millega õpetajad on kokku puutunud, ning tööga seotud nostalgilistest mälestustest.
\end{abstract}

Võtmesõnad: professionaalne mälu, muutused kutseõppeasutuste õpilaskonnas, kutseõpetajate kogemused

\section{Sissejuhatus}

Mitmesugused muutused kutsehariduses on mõjutanud kutseõpetajate professionaalsusele esitatavaid nõudmisi. Esiteks on muutunud rangemaks kutseõpetajate haridusnõuded, teiseks on mitmekesistunud nende igapäevatöö ning kolmandaks ootavad tööandjad, et kutseõppeasutused ja seega kutseõpetajad tagaksid lõpetajatele töömaailmas toimetulekuks üha paremad erialased ja üldpädevused (Sirk, Liivik, \& Loogma, 2016). Rangematest nõudmistest ja

Haridusteaduste instituut, Tallinna Ülikool, Narva mnt 25, 10120 Tallinn; meidi.sirk@tlu.ee 
tööalastest muutustest hoolimata peavad kutseõpetajad suurimaks raskuseks õpilaskonnas toimunud muutusi, mis on oluliselt mõjutanud nende igapäevast tööd (van Middelkoop, Ballafkih, \& Meerman, 2017; Sirk et al., 2016). Õpilaste õpi- ja käitumisraskused, motivatsioonipuudus ning perede puudulik tugisüsteem on lisanud kutseõpetajatele uusi rolle, nagu sotsiaaltöötaja, vanemliku toe pakkuja, juhendaja, mentor ja nõustaja (Cort \& Rolls, 2010; Hughes \& Attwell, 2010; Kats, van Lakerveld, \& Smit, 2010; Sirk et al., 2016; Susimetsä, 2010), ning nõuab neilt üha enam sotsiaalpedagoogilisi ja psühholoogilisi pädevusi (Kirpal, 2011).

Varasemate uurimuste põhjal on teada, et kutseõpetajad kogevad haridusmuutusi ja nendega kaasnenud nõudmisi erinevalt ning nende arusaam oma professionaalsusest võib omakorda mõjutada muutuste tajumist ja omaksvõttu (Rekkor, Ümarik, \& Loogma, 2013; Tafel-Viia, Loogma, Lassur, \& Roosipõld, 2012; Vähäsantanen \& Eteläpelto, 2011; Ümarik \& Rekkor, 2013). Varasemates uurimustes ei ole aga käsitletud seda, kuidas õpilaskonnas tajutud negatiivsed arengutendentsid või kogemused sõltuvad kutseõpetajate endi professionaalsetest kogemustest või demograafilistest tunnustest.

Hargreaves (2005) on rõhutanud, et muutuste tajumisel on olulised õpetajate vanus ja pedagoogilise kogemuse pikkus, mis on seotud tema professionaalse mälu kujunemisega. Seetõttu suhtuvad nooremad ja väiksema pedagoogilise kogemusega õpetajad muutustesse üldjuhul positiivsemalt. Kuna professionaalne mälu sisaldab mälestusi ametialastest sündmustest (Tarpey, 2015), millega kaasnevad emotsioonid (Ben-Peretz, 2002) ja nostalgia (Goodson, Moore, \& Hargreaves, 2006), siis mõjutab see professionaalseid teadmisi ja tavasid (Ben-Peretz, 2002). Lisaks seostub professionaalse mäluga professionaalse identiteedi loomine ehk enda mõtestamine muutuste kontekstis ja toimetulek muutunud tööga (Goodson et al., 2006; Tarpey, 2016). Siinses uurimuses võimaldab professionaalse mälu kontseptsioon mõtestada kutseõpetajate negatiivseid hoiakuid õpilaskonna muutuste suhtes, mida varasemad uurimused ei ole avanud. Sellest lähtudes seadsime eesmärgiks selgitada kutseõpetajate kogetud muutusi õpilaskonnas, tuginedes professionaalse mälu kontseptsioonile. Uurimuses otsime vastuseid järgmistele uurimisküsimustele.

1. Kuidas kutseõpetajad eristuvad õpilaskonnas kogetud muutuste alusel?

2. Kuidas seostuvad professionaalse mälu karakteristikud (pedagoogiline staaž ja vanus) kutseõpetajate kogetud muutustega õpilaskonnas?

3. Millised kutseõpetajate demograafilised (sugu, keel) ja kooli tunnused (õpilaste arv koolis, kooli asukoht, õpperühmad, õpetatav valdkond) seostuvad muutustega, mida kutseõpetajad on kogenud kutsehariduse õpilaskonnas?

4. Mis tähendusi omistavad kutseõpetajad kutseõppeasutuse õpilaskonnas toimunud muutustele? 
Esmalt analüüsime kvantitatiivseid andmeid, kirjeldades muutusi, mida kutseõpetajad on õpilaskonnas kogenud, ning nende seost professionaalse mälu karakteristikute, demograafiliste ja kooli tunnustega. Seejärel avame kvalitatiivsete poolstruktureeritud temaatiliste intervjuude (Mason, 2002) analüüsi tulemustele toetudes tähendusi, mida kutseõpetajad on õpilaskonna muutustele omistanud.

\section{Õpetajate professionaalne mälu: teoreetilised käsitlused}

Professionaalse mälu (professional memory, PM) mõiste on mitmetähenduslik. Sotsioloogilisest aspektist tähistab professionaalne mälu mälestust, mis on seotud mällu talletunud elamuste või kogemustega, millega kaasnevad teatud emotsioonid (Ben-Peretz, 2002) ja nostalgia (Goodson et al., 2006). Seega viitab professionaalse mälu mõiste õpetajate emotsionaalsetele mälestustele oma professionaalsest praktikast (Tarpey, 2015), olles sotsiaalselt konstrueeritud (Ben-Peretz, 2002; Goodson et al., 2006; Tarpey, 2015, 2016).

Professionaalne mälu muutub kogemuste lisandumise tõttu järjepidevalt. Nii võidakse tööd mõjutavate tegurite toimel omaks võtta uusi arusaamu, hoiakuid ja ülesandeid. Näiteks võivad mõned sündmused õpetajate töös olla tähendusrikkamad ja mõjutada nende edasist professionaalset käitumist, mistõttu on neid nimetatud ka kriitilisteks intsidentideks (Ben-Peretz, 2002). Tavaliselt mäletatakse ja kirjeldatakse neid sündmusi/kogemusi detailirohkelt. Õpetajad meenutavad oma tööelu sündmusi, toiminud reegleid ja põhimõtteid ning kujundavad kogetu põhjal uued teadmised ja arusaamad. Samas võtab õppimine oma kogemustest aega, toimudes interaktsioonis teiste kogemustega, ning nõuab avatust ja küpsust (pedagoogilist kogemust), millega kaasneb professionaalne tarkus ja professionaalse mälu kujunemine (ibid.).

Õpetajate professionaalses mälus avalduvad jagatud kollektiivsed professionaalsed tavad, hoiakud ja uskumused ning professionaalne areng. Mälestused ei saa olla isoleeritud, vaid need kuuluvad alati mingisse konteksti, kultuuriruumi ja perioodi (Tarpey, 2009, 2015). Tööga seotud mälestused peegeldavad muutusi haridussüsteemis ja ühiskonnas laiemalt (Ben-Peretz, 2002; Tarpey, 2009) ning õpetajate kogemusi ja tegelikke arusaamu muutustest (Goodson, 2003), pakkudes selgitusi möödunule (Tarpey, 2015) või kandes kasulikke tavasid üle järgmistele põlvkondadele (Tarpey, 2016).

Hargreavesi (2005) järgi sõltub muutuste kogemine ja neisse suhtumine ópetajate vanusest ja pedagoogilisest staažist, kuid ka teised individuaalsed karakteristikud võivad seda mõjutada. Ta eristab kolme õpetajate pedagoogilise kogemuse etappi, mis peegeldavad professionaalse mälu kujunemist. Pedagoogilise kogemuse etappide järgi kohanevad oma karjääri alguses olevad 
ehk kuni viieaastase pedagoogilise staažiga õpetajad muutustega paremini ja suhtuvad neisse entusiastlikumalt kui vanemad kolleegid. Selliseid positiivsemaid hoiakuid seletatakse professionaalse mälu puudumisega, mille tõttu ei saa nad võrrelda muutust oma varasemate kogemustega. Õpetajad, kes lähenevad karjäriri lõpule ehk kel on vähemalt 20-aastane pedagoogiline staaž, püüavad säästa oma energiat ja vältida uuendusi. Oma karjääri keskel olevad õpetajad (6-19 aastat staaži) on muutuste suhtes enesekindlamad. Neil on piisavalt professionaalseid kogemusi ja energiat, et reageerida muutustele entusiastlikult.

Õpetaja professionaalset mälu käsitledes tuleb arvestada, et tänapäeva nooremad õpetajad ei pruugi olla samasugused, kui olid eakamad õpetajad oma noorusajal, kuna laiem sotsiaalne, kultuuriline ja poliitiline sündmustik mõjutab õpetajate identiteedi ja tööalaste hoiakute kujunemist (Cunningham, 2007; Goodson et al., 2006; Tarpey, 2016). Professionaalne mälu võib sisaldada nostalgiat möödunu suhtes, mõjutades seeläbi uute muutustega kohanemist, eriti pensionieale lähenevate õpetajate seas (Goodson et al., 2006). Nostalgia, samamoodi nagu professionaalne mälu, aitab kutseõpetajal kriitiliselt mõtestada toimunud muutusi ja ennast kui kutseõpetajat muutunud töörollides (Ümarik \& Goodson, 2018). Seega on nostalgial professionaalse mälu kontekstis nii negatiivne kui ka positiivne tähendus.

Professionaalne mälu, olles seotud individuaalsete mälestustega, kuid olles samal ajal sotsiaalselt konstrueeritud ja moodustades osa kollektiivsest mälust, võimaldab mõista ametialase rühma arusaama mingist uuritavast objektist, nt õpetajate hoiakuid, väärtuseid, tavasid ja/või kogemusi kindlas kontekstis (Tarpey, 2009, 2015, 2016). Seejuures tuleb arvestada, et õpetajad, jutustades oma tööga seotud mälestustest, võivad seda teha valikuliselt, unustades midagi või jättes mõned olulised sündmused tähelepanuta (Ben-Peretz, 2002; Gardner, 2003), mida võib käsitleda siinses uurimuses ka teatava piiranguna. Näiteks on Gardner (2003) väitnud, et meenutused indiviidi tööelu sündmustest, sh emotsioonidest, räägivad pigem jutustajast endast, mitte n-ö objektiivsetest nähtustest, olles valikulised ja väljendades soovi teha oma tööelu tähenduslikuks.

Seega, professionaalse mälu kontseptsioon sisaldab eri dimensioone. Siinses analüüsis lähtume: 1) professionaalset mälu iseloomustavatest karakteristikutest - kutseõpetajate vanusest ja pedagoogilise kogemuse pikkusest; 2) tähendusrikastest sündmustest, mis mõjutavad professionaalset tegevust/käitumist, avalduvad personaalsetes ja kollektiivsetes kogemustes ning võivad tuleneda hariduspoliitilistest muutustest; 3) kutseõpetajate emotsionaalsetest ja nostalgilistest mälestustest, mis kujundavad tähendusi, mille õpetajad omistavad muutustele. 


\section{Muutused kutsehariduse õpilaskonnas}

\section{Õpilaskonna muutusi mõjutanud kutsehariduspoliitilised sündmused Eestis}

Kutsehariduse riiklik korraldamine algas 1990ndate lõpus ja üldised arengusuunad määrati kindlaks kutseharidussüsteemi arengukavades, mis kehtisid 2001. aastast 2013. aastani. Läbivalt on tähtsustatud kutsehariduse paindlikkust ning erialase ettevalmistuse kõrval ka kutseõppe sotsiaalset ja kaasavat funktsiooni (Eesti kutseharidussüsteemi arengukava, 2005, 2009; Tegevuskava ..., 2001), et valmistada ette eri sihtrühmi kodanikuühiskonnas ja tööturul osalemiseks ning õpi- ja tööalaste võimaluste säilitamiseks (Loogma, 2013). Kutseharidus on muutunud avatuks ja kättesaadavaks kõigile soovijatele, sh akadeemiliselt vähem võimekatele noortele, seni kutseharidusest eemale jäänutele ja erivajadustega õppijatele (Statistikaamet, 2007; Ümarik \& Rekkor, 2013), kelle arv Eesti kutseõppeasutustes on kasvanud viimase kümne aasta jooksul ligi 30\% (Haridusilm, 2018).

Kutsehariduse kättesaadavuse tagamiseks kehtestati 2005. aastal kutseõppeasutuse seadusega uued kutseõppe liigid, võimaldades põhiharidusnõudeta ja üldkeskhariduseta põhikoolijärgset kutseõpet. Lisaks seadustati senise koolipõhise õppe kõrval töökohapõhine õpe (Statistikaamet, 2007). Aasta-aastalt on õppijate arv uutes kutseõppe liikides kasvanud. Näiteks aastatel 2006-2008 suurenes õppijate arv põhiharidusnõudeta ja põhihariduse baasil toimuvas kutseõppes ligi 59\% (Eesti kutseharidussüsteemi arengukava, 2009) ning viimase kümne aasta jooksul töökohapõhises õppes 77\% (Haridussilm, 2018).

Juba aastaid on olnud kutsehariduspoliitika fookuses õppijate arvu suurendamine kutseõppe kvaliteedi ja maine parandamise kaudu (Eesti kutseharidussüsteemi arengukava, 2005, 2009). Haridusstatistika järgi on aastatel 2005-2017 keskmiselt 27\% põhikooli lõpetajatest siirdunud kutseharidusse, 69\% üldharidusse ja 4\% ei jätka õpinguid (Haridussilm, 2018). Kui esimeses Eesti kutsehariduse arengukavas seati ambitsioonikaks eesmärgiks, et 50\% põhikooli lõpetanutest siirdub kutseõppesse (Tegevuskava ..., 2001), siis aastaks 2020 on seatud realistlikum eesmärk - suurendada kutseõppurite osakaalu 35\%-ni (Cedefop, 2017), et tagada tööturu nõudlus kutseharidusega spetsialistide järele. Kui õpingute jätkamine kutsehariduses ei ole noorukite hulgas populaarne, siis märkimisväärselt on kasvanud täiskasvanud õppijate huvi kutsehariduse vastu. Üle 25-aastaste õppijate osakaal on ajavahemikus 20072017 suurenenud 56\%, moodustades 2017. aastal juba 35\% kogu kutsehariduse õpilaskonnast (Haridussilm, 2018). Üha levinum on selline muster, mille korral valitakse kutseharidus peale kõrghariduse omandamist, et täiendada oma 
teoreetilisi teadmisi praktiliste oskustega, kasvatada konkurentsivõimet tööturul või omandada südamelähedane huviala (Riigikontroll, 2016).

Üks kutsehariduse murekohti on olnud aasta-aastalt suurenev õpilaste väljalangemus, mis 2001. aastal oli 13\% (Tegevuskava ..., 2001) ja 2016/2017. õppeaastal juba 20\% (Haridussilm, 2018). Seetõttu seati kutsehariduse kolmandas arengukavas üheks oluliseks prioriteediks väljalangemuse vähendamine. Samuti rõhutati õppijakesksust ja vajadust läheneda igale õppijale individuaalselt (Eesti kutseharidussüsteemi arengukava, 2009). Õppija arengu aspekti tähtsustatakse ka 2020. aastani kehtivas Eesti elukestva õppe strateegias (2014), kus ühe strateegilise tegevusena nähakse erialase kvalifikatsiooniga inimeste arvu suurendamist, pakkudes neile võrdseid võimalusi elukestvaks õppeks, sh luues ka nõrgema konkurentsivõimega inimestele tingimused õppes osalemiseks. Ka aastate 2018-2021 kutseharidusprogrammi (2018) üks eesmärke on välja töötada kontseptsioon täiskasvanute tagasitoomiseks kutseharidusse.

Eelnevast võib näha, et kutsehariduspoliitilised eesmärgid ja arengusuundumused on toetanud õpilaskonna jätkuvat mitmekesistumist.

\section{Kutseõpetajate kogetud muutused õpilaskonnas}

Kutseõpetajatega tehtud rahvusvahelised ja Eesti-sisesed uuringud peegeldavad sarnaseid tendentse õpilaskonnas. Kutseõpetajate hinnangul on õpilaskond muutunud mitmekesiseks, pidades silmas õppijate tausta, vanust, varasemaid teadmisi ja oskusi ning motivatsiooni (van Middelkoop et al., 2017; Ümarik \& Rekkor, 2013). Seetõttu on õpperühmade üldine tase ja motiveeritus ebaühtlased, varieerudes lisaks eriala, õppekeele või õppeaasta arvestuses (Tamm, 2011).

Peamine õppijaid eristav näitaja on vanuseline koosseis, millest tulenevad paljud teised muutused (Cort \& Rolls, 2010). Probleemsed muutused on enamasti seotud just noorukiealiste (15-19) ja pigem meessoost õppijatega (van Middelkoop et al., 2017). Näiteks on kutseõpetajad kogenud noorte õppijate perekondliku toe vähenemist mitmel moel (Espenberg, Beilmann, Rahnu, Reincke, \& Themas, 2012; van Middelkoop et al., 2017) ning seetõttu on kasvanud nende töös vajadus tegeleda õppijate sotsiaalsete ja personaalsete probleemidega (van Middelkoop et al., 2017; Ümarik \& Rekkor, 2013). Täheldatud on, et noored õppijad on muutunud neid ümbritseva suhtes ükskõiksemaks, laisemaks ja ebaküpsemaks ning neil on raskusi vastutuse võtmisega (Cort \& Rolls, 2010; Kats et al., 2010; Susimetsä, 2010). Lisaks on kujunenud õppimisel takistuseks õpilaste puudulikud õpi- ja põhioskused (Espenberg et al., 2012; Hughes \& Attwell, 2010; van Middelkoop et al., 2017; Ümarik \& Rekkor, 2013). Noorte suulise ja kirjaliku eneseväljenduse oskus on kutse- 
õpetajate hinnangul halvenenud ning nad pigem väldivad otsest kontakti õpetajatega, eelistades suhtluskanalina sotsiaalmeediat (Espenberg et al., 2012). Õpilaste suhtlemine õpetajatega on muutunud võrdsemaks ja sõbralikumaks (Hughes \& Attwell, 2010; Ümarik \& Rekkor, 2013).

Kutseõpetajate kogemused täiskasvanud õppijatega on positiivsemad. Täiskasvanud õppijad on eri haridustaseme ja kogemustega, motiveeritumad ning õppijatena nõudlikumad, esitades suuremaid ootusi kutseõpetajatele õppekvaliteedi suhtes (Cort, 2010; Hughes \& Attwell, 2010).

Õpilaskonna muutustega on kaasnenud kutseõpetajate pädevuste ja ametirollide mitmekesistumine (sotsiaaltöötaja, kasvataja, vanemate asendaja, mentor, tuutor, õppimise toetaja, nõustaja, täiskasvanute koolitaja jt) ning nende ümbermõtestamise vajadus (Cort \& Rolls, 2010; Hughes \& Attwell, 2010; Kats et al., 2010; Susimetsä, 2010; Ümarik \& Rekkor, 2013). Kutseõpetajad on tunnistanud, et neil jääb vajaka teadmistest ja oskustest, kuidas didaktiliselt arvestada õppijate kõigi iseärasustega (Tamm, 2011). Teisalt on nad tundnud, et neil ei ole piisavalt aega arvestada iga õppija individuaalsust, sest see nõuaks teistsugust lähenemisviisi, sh meetodite rakendamist ja lisajuhendamist klassiruumis (van Middelkoop et al., 2017). Ümarik ja Rekkor (2013) toovad esile ka nn vana kooli õpetajate põhjendused selle kohta, miks rakendatakse nõrkade õpilaste õpetamisel õpetajakeskseid õppemeetodeid: puudulike õpioskuste ja distsipliini tõttu ei ole võimalik teisi meetodeid rakendada. Eesti kutseõpetajate lood muutustest õpetajatöös peegeldavad sageli nostalgiat, mis on seotud nende töökarjääri algusega, mil kutseharidus ja õpetatav valdkond olid populaarsemad, õppurid motiveeritumad ning oma haridusvalikutes teadlikumad (Ümarik \& Goodson, 2018).

Varasemad uurimused on viidanud kutseõpetajate erinevatele, kuid peamiselt negatiivsetele kogemustele, mille tõttu levib arusaam, et kutsehariduse õpilaskond on muutunud probleemsemaks. Samas ei ole uurimustes analüüsitud, kuidas hinnangud õpilaskonnale on seotud kutseõpetajate endi karakteristikutega. Professionaalse mälu kontseptsioon võimaldab analüüsida, kuidas kutseõpetajad, toetudes oma kogemustele ja neile omistatud tähendustele, konstrueerivad praegu pilti ópilastest ja oma muutunud töörollidest.

\section{Metoodika}

\section{Valim ja andmestik}

Artikkel põhineb kombineeritud uurimisviisil (Creswell, 2010), mille korral koguti andmeid kvantitatiivse küsitluse ja kvalitatiivse poolstruktureeritud intervjuudega. 
Küsitluse kõiksesse valimisse (Creswell, 2012) kaasati Eesti kutseõppeasutused, kuid osalemisnõusolek saadi 32 kutseõppeasutuselt (86,5\%). Välja saadeti 1685 e-küsimustikku, millest täideti 501, mis moodustab 22\% üldkogumist. Küsimustikule vastanutest $65,5 \%$ oli naissoost, ülejäänud meessoost kutseõpetajad. $87 \%$ vastanutest täitis küsimustiku eesti keeles, ülejäänud vene keeles. Vastanute pedagoogiline töökogemus ulatus poolest aastast 48 aastani ja keskmine kogemus oli 15 aastat $(S D=10,97)$. Vanuse alusel kuulus kõige rohkem vastanutest (34\%) 55-aastaste ja vanemate kutseõpetajate vanuserühma. $31 \%$ olid vanuses $45-54$ aastat, $21 \% 35-44$ aastat ja $14 \%$ alla 34 -aastased. Vastanute jaotust võrreldi üldkogumi jaotusega vanuse, soo ja makonna kaupa.

Küsitluse eesmärk oli uurida kutseõpetajate professionaalsust, tööelu ja muutusi nende töös. Selleks koostati küsimustik, mis koosnes kuuest osast. Siinses artiklis kasutame kahte osa (kutseõpetajate taust, muutused õpetajatöös), mille koostamisel tuginesime hariduspoliitiliste muutuste analüüsile ja 2014. aastal tehtud intervjuude esmasel analüüsil loodud alakategooriate tulemustele. Küsimustikku katsetati ja põhiküsitlus tehti 2015. aastal. Küsimustiku osast, mille keskmes on õpetajatöö muutused, kasutame ainult õpilaskonna muutusi käsitlevat alaosa, kus kutseõpetajatel paluti hinnata oma töötatud aja jooksul õpilaskonnas toimunud muutusi. Hinnanguid anti 16 algtunnusele Likerti viiepalliskaalal (5 - oluliselt paranenud, 4 - mõnevõrra paranenud, 3 - pole muutunud, 2 - mõnevorrra halvenenud, 1 - oluliselt halvenenud) (vt tabel 1).

Intervjuude sihipärasesse valimisse (Creswell, 2012) kaasati 20-30-aastase tööstaažiga kutseõpetajad eeldusega, et nende professionaalne mälu hõlmab mitmekesisemaid kogemusi kutseharidusmuutustest (sh õpilaskonna muutustest). Intervjueeritavate leidmiseks ja intervjueerimisloa saamiseks pöörduti seitsme kutseõppeasutuse õppejuhi poole. Kooli luba ja kutseõpetajate kontaktid saadi kõigist kutseõppeasutustest. Seejärel võeti kutseõpetajatega ühendust ning intervjueerimise nõusolek saadi üheksalt. Individuaalintervjuudes (Mason, 2002) osalenud kutseõpetajad olid eri kutseharidusvaldkondadest (tehnikaalad, tootmine ja töötlemine, metsandus, isikuteenindus). Nende tööstaaž jäi vahemikku 25-47 aastat ja vanus vahemikku 52-72 aastat. Kolm respondenti olid mehed.

Intervjueerimise eesmärk oli teada saada, mis muutusi on kutseõpetajad kogenud oma tööelus ja professionaalsuses. Selleks koostati varasemate uurimuste analüüsile tuginedes temaatilise poolstruktureeritud intervjuu juhend (Mason, 2002), mis hõlmas kuut teemat. Selles artiklis keskendume teemale, mis kajastas õpilaskonna muutusi. Intervjuud tehti 2014. aastal ning need kestsid 1-2 tundi. Intervjuud salvestati diktofoniga. 


\section{Andmeanalüüsi meetodid}

Uurimisküsimustele vastamiseks analüüsisime esmalt statistikapaketi SPSS 25.0 abil kutseõpetajate kogetud muutusi õpilaskonnas, toetudes kvantitatiivsele andmestikule. Kuna algtunnuseid oli palju ja osa neist mõõtis ühte suuremat õpilaskonna muutuse fenomeni, lõime algtunnuste korreleerumise ja sisulise sobivuse alusel liittunnused, mille usaldusväärsust kontrollisime Cronbachi alfaga. 16 algtunnusest saime kuus liittunnust (vt tabel 1). Seejärel kasutasime $k$-keskmiste klasteranalüüsi, et eristada kutseõpetajate kogetud muutusi õpilaskonnas. Kogemuste põhjal eristuvaid kutseõpetajate rühmi võrdlesime liittunnuste alusel, kasutades ANOVA ja Bonferroni paariviisiliste võrdluste testi (vt tabel 2). Kutseõpetajate rühmi võrdlesime omakorda professionaalse mälu karakteristikute, demograafiliste ja kooli tegurite alusel, kasutades selleks risttabelit. Erinevuste statistilist olulisust kontrollisime hii-ruut-testiga (vt tabel 3).

Tabel 1. Liittunnuste moodustamine õpilaskonnas kogetud muutuste algtunnustest

\begin{tabular}{|c|c|c|c|}
\hline Algtunnused & Liittunnused & $M$ & $S D$ \\
\hline $\begin{array}{l}\text { - Perede toetus õppijatele õpingute ajal } \\
\text { - Õpilaste majanduslik olukord } \\
\text { - Õppijate tervislik seisund }\end{array}$ & $\begin{array}{l}\text { Õpilaste heaolu } \\
\text { Cronbachi } a=0,74\end{array}$ & 2,80 & 0,67 \\
\hline $\begin{array}{l}\text { - Õpilaste vastutus- ja kohusetunne } \\
\text { - Õpilaste suhtumine õppimisse } \\
\text { - Õpilaste õpimotivatsioon }\end{array}$ & $\begin{array}{l}\text { Õpilaste suhtumine } \\
\text { ôppimisse } \\
\text { Cronbachi } a=0,93\end{array}$ & 2,69 & 0,93 \\
\hline $\begin{array}{l}\text { - Õpilaste õpioskus } \\
\text { - Õpilaste süvenemine ja tähelepanu } \\
\text { õppimisel }\end{array}$ & $\begin{array}{l}\text { Õpilaste üldine õpioskus } \\
\text { Cronbachi } a=0,87\end{array}$ & 2,53 & 0,92 \\
\hline $\begin{array}{ll}\text { - } & \text { Õpilaste lugemus } \\
\text { - } & \text { Õpilaste arusaamine loetust } \\
\text { - } & \text { Õpilaste emakeeleoskus, suuline ja kirjalik } \\
& \text { väljendusoskus } \\
\text { - } & \text { Oppilaste matemaatikapädevused }\end{array}$ & $\begin{array}{l}\text { Õpilaste põhiteadmised ja } \\
\text {-oskused } \\
\text { Cronbachi } a=0,88\end{array}$ & 2,31 & 0,78 \\
\hline $\begin{array}{l}\text { - Õpilaste omavaheline läbisaamine } \\
\text { - Õpilaste kultuuriteadlikkus, tolerantsus } \\
\text { ja sallivus kaaslaste suhtes }\end{array}$ & $\begin{array}{l}\text { Õpilaste tolerantsus ja } \\
\text { omavaheline läbisaamine } \\
\text { Cronbachi } a=0,83\end{array}$ & 3,20 & 0,79 \\
\hline $\begin{array}{l}\text { - Õpilaste ettevõtlikkus ja algatusvõime } \\
\text { - OOpilaste ühiskondlik ja kodanikuaktiivsus }\end{array}$ & $\begin{array}{l}\text { Õpilaste aktiivsus ja } \\
\text { ettevõtlikkus } \\
\text { Cronbachi } a=0,73\end{array}$ & 3,10 & 0,76 \\
\hline
\end{tabular}

Et avada õpilaskonnas kogetud muutuste tähendusi, analüüsisime kutseõpetajatega tehtud kvalitatiivseid poolstruktureeritud intervjuusid, toetudes temaatilise analüüsi meetodile (Braun \& Clarke, 2006). Kõigepealt lugesid kaks uurijat 
sõna-sõnalt transkribeeritud intervjuude terviktekstid läbi ja tähistasid õpilaskonna muutustega seotud osad. Neid tekstiosi loeti korduvalt ning lugemise käigus märgiti kvantitatiivsetest algtunnustest lähtudes esmased koodid, nt õpilaste õpioskus (vt tabel 1). Uurijad arutasid esmased koodid läbi ja sõnastasid vajaduse korral need ümber. Seejärel paigutati õpilaskonna muutustega seotud koodid kvantitatiivse küsitluse liittunnuste alusel eelmääratud kategooriatesse, nt õpilaste üldine õpioskus (vt tabel 1). Viimaks tõlgendati analüüsi tulemusi, avades tähendusi, mille kutseõpetajad on õpilaskonna muutustele omistanud, ning seostades need professionaalse mälu kontseptsiooni dimensioonidega.

\section{Tulemused}

\section{Kutseõpetajate rühmad õpilaskonnas kogetud muutuste alusel}

Klasteranalüüsi tulemusena osutus parimaks kolmest klastrist koosnev mudel, mis võimaldab eristada kutseõpetajate kogemusi. Õpilaskonna muutusi iseloomustavad tunnused (õpilaste heaolu, suhtumine õppimisse, üldine õpioskus, põhiteadmised ja -oskused, tolerantsus ja omavaheline läbisaamine, aktiivsus ja ettevõtlikkus) eristusid üksteisest statistiliselt olulisel määral (vt tabel 2).

Tabel 2. Kutseõpetajate rühmad õpilaskonnas kogetud muutuste alusel

\begin{tabular}{|c|c|c|c|c|c|c|}
\hline $\begin{array}{c}\text { Õpilaskonna } \\
\text { muutuste tunnused }\end{array}$ & $M / S D$ & $\begin{array}{c}\text { I } \\
\text { positiivsed } \\
\text { kogemused } \\
n=122 \\
(24 \%)\end{array}$ & $\begin{array}{c}\text { II } \\
\text { varieeruvad } \\
\text { kogemused } \\
n=228 \\
(46 \%)\end{array}$ & $\begin{array}{c}\text { III } \\
\text { negatiivsed } \\
\text { kogemused } \\
n=151 \\
(30 \%)\end{array}$ & $F$ & $p$ \\
\hline Õpilaste heaolu & $\begin{array}{l}M \\
S D\end{array}$ & $\begin{array}{l}3,22^{(I I j a ~ I I I)} \\
0,67\end{array}$ & $\begin{array}{l}2,85^{(\text {l ja III) }} \\
0,56\end{array}$ & $\begin{array}{l}2,37^{(\text {l ja II) }} \\
0,55\end{array}$ & 72,79 & 0,00 \\
\hline $\begin{array}{l}\text { Õpilaste suhtumine } \\
\text { õppimisse }\end{array}$ & $\begin{array}{l}M \\
S D\end{array}$ & $\begin{array}{l}3,80^{(I I ~ j a ~ I I I) ~} \\
0,52\end{array}$ & $\begin{array}{l}2,72^{(\text {I ja III) }} \\
0,56\end{array}$ & $\begin{array}{l}1,74^{(\text {l ja II) }} \\
0,55\end{array}$ & 475,25 & 0,00 \\
\hline $\begin{array}{l}\text { Õpilaste üldine } \\
\text { õpioskus }\end{array}$ & $\begin{array}{l}M \\
S D\end{array}$ & $\begin{array}{l}3,67^{(\text {II a III) }} \\
0,55\end{array}$ & $\begin{array}{l}2,53^{(\text {I j IIII) }} \\
0,54\end{array}$ & $\begin{array}{l}1,62^{(\text {l a II) }} \\
0,49\end{array}$ & 511,06 & 0,00 \\
\hline $\begin{array}{l}\text { Õpilaste põhitead- } \\
\text { mised ja-oskused }\end{array}$ & $\begin{array}{l}M \\
S D\end{array}$ & $\begin{array}{l}3,20^{(\text {II j a III) }} \\
0,64\end{array}$ & $\begin{array}{l}2,33^{(\text {I ja III) }} \\
0,47\end{array}$ & $\begin{array}{l}1,55^{(\text {l j III) }} \\
0,42\end{array}$ & 365,69 & 0,00 \\
\hline $\begin{array}{l}\text { Õpilaste tolerantsus } \\
\text { ja omavaheline } \\
\text { läbisaamine }\end{array}$ & $\begin{array}{l}M \\
S D\end{array}$ & $\begin{array}{l}3,89^{(\text {II j a III) }} \\
0,62\end{array}$ & $\begin{array}{l}3,25^{(\text {l ja III) }} \\
0,53\end{array}$ & $\begin{array}{l}2,57^{(\text {l ja II) }} \\
0,73\end{array}$ & 153,43 & 0,00 \\
\hline $\begin{array}{l}\text { Õpilaste aktiivsus ja } \\
\text { ettevõtlikkus }\end{array}$ & $\begin{array}{l}M \\
S D\end{array}$ & $\begin{array}{l}3,76^{(I \mathrm{j} \text { a III) }} \\
0,50\end{array}$ & $\begin{array}{l}3,22^{(\text {I ja III) }} \\
0,47\end{array}$ & $\begin{array}{l}2,33^{(\text {j j all })} \\
0,65\end{array}$ & 253,09 & 0,00 \\
\hline
\end{tabular}

Märkus. Kogemuste keskväärtuste juurde on märgitud, millistest teistest kogemustest nad eristuvad statistiliselt olulisel määral $(p<0,05)$. 
Kutseõpetajate rühmad erinesid üksteisest statistiliselt olulisel määral kutseõpetajate pedagoogilise staaži, vanuse, kooli suuruse (õpilaste arvu) ja õpetatava õpperühma poolest (vt tabel 3). Esimene rühm kutseõpetajaid (24\%) on tajunud pigem positiivsemaid muutusi, seda eriti ópilaste tolerantsuses, omavahelises läbisaamises, suhtumises õppimisse, aga ka aktiivsuses ja ettevõtlikkuses. Siia rühma kuulub rohkem nooremaid ja lühema pedagoogilise staažiga kutseõpetajaid. Lisaks õpetavad nad väiksema õpilaste arvuga kutseõppeasutustes ning vähem põhikoolijärgseid õpperühmi. Seevastu teise rühma kuuluvate kutseõpetajate (46\%) kogemused õpilaskonna muutustega on varieeruvad ja vähem positiivsed võrreldes esimese rühma omadega: nad on pigem kogenud õpilaste põhiteadmiste ja -oskuste ning üldise õpioskuse halvenemist. Õpilaste tolerantsuses, aga ka aktiivsuses ja ettevõtlikkuses ei ole muutust väga kogetud. Siia rühma kuuluvad enamjaolt pikema pedagoogilise staažiga ja vanemad kutseõpetajad, kes õpetavad eri suurusega kutseõppeasutustes ja eri tasemega õpperühmi. Kolmandasse rühma kuuluvad õpilaskonna muutusi valdavalt negatiivselt hinnanud kutseõpetajad (30\%), kes on oma tööaja jooksul täheldanud õpilaste heaolu, suhtumise, õpioskuste, põhiteadmiste ja -oskuste ning ettevõtlikkuse ja aktiivsuse halvenemist. Selle rühma kutseõpetajad on enamasti pedagoogilise staažiga 6-19 aastat ja vanuserühmast 35-54 aastat. Nad õpetavad suuremates kutseõppeasutustes ja rohkem põhikoolijärgseid rühmi.

Tabel 3. Kutseõpetajate rühmade võrdlemine professionaalse mälu karakteristikute ja kooli tegurite alusel

\begin{tabular}{|c|c|c|c|c|c|c|c|}
\hline \multicolumn{2}{|c|}{$\begin{array}{l}\text { Professionaalse mälu } \\
\text { karakteristikud ja kooli tegurid }\end{array}$} & $n=24 \%$ & $\begin{array}{c}\text { II } \\
n=46 \%\end{array}$ & $\begin{array}{c}\text { III } \\
n=30 \%\end{array}$ & $\begin{array}{l}\text { kokku } \\
100 \%\end{array}$ & $x^{2}$ & $p$ \\
\hline \multirow{3}{*}{$\begin{array}{l}\text { Pedagoogiline } \\
\text { kogemus } \\
d f=4\end{array}$} & Kuni 5 aastat & $39 \%$ & $45 \%$ & $16 \%$ & $100 \%$ & \multirow{3}{*}{23,10} & \multirow{3}{*}{0,00} \\
\hline & 6-19 aastat & $21 \%$ & $43 \%$ & $36 \%$ & $100 \%$ & & \\
\hline & 20 ja rohkem aastat & $19 \%$ & $51 \%$ & $30 \%$ & $100 \%$ & & \\
\hline \multirow{4}{*}{$\begin{array}{l}\text { Kutse- } \\
\text { õpetajate } \\
\text { vanus } \\
d f=6\end{array}$} & Kuni 34-aastased & $40 \%$ & $33 \%$ & $26 \%$ & $100 \%$ & \multirow{4}{*}{15,42} & \multirow{4}{*}{0,02} \\
\hline & 35-44-aastased & $26 \%$ & $40 \%$ & $34 \%$ & $100 \%$ & & \\
\hline & 45-54-aastased & $20 \%$ & $49 \%$ & $31 \%$ & $100 \%$ & & \\
\hline & $\begin{array}{l}55 \text {-aastased ja } \\
\text { vanemad }\end{array}$ & $20 \%$ & $51 \%$ & $29 \%$ & $100 \%$ & & \\
\hline
\end{tabular}




\begin{tabular}{|c|c|c|c|c|c|c|c|}
\hline \multicolumn{2}{|c|}{$\begin{array}{l}\text { Professionaalse mälu } \\
\text { karakteristikud ja kooli tegurid }\end{array}$} & \multirow{2}{*}{$\begin{array}{c}\begin{array}{c}\text { I } \\
n=24 \%\end{array} \\
57 \%\end{array}$} & \multirow{2}{*}{$\begin{array}{c}\begin{array}{c}\text { II } \\
n=46 \%\end{array} \\
43 \%\end{array}$} & \multirow{2}{*}{$\begin{array}{c}\begin{array}{c}\text { III } \\
n=30 \%\end{array} \\
0 \%\end{array}$} & \multirow{2}{*}{$\begin{array}{r}\text { kokku } \\
100 \%\end{array}$} & \multirow[t]{2}{*}{$x^{2}$} & \multirow{2}{*}{$p$} \\
\hline \multirow{6}{*}{$\begin{array}{l}\text { Õpilaste arv } \\
\text { koolis } \\
d f=10\end{array}$} & Kuni 100 & & & & & & \\
\hline & $101-300$ & $34 \%$ & $50 \%$ & $16 \%$ & $100 \%$ & \multirow{5}{*}{32,06} & \multirow{5}{*}{0,00} \\
\hline & $301-500$ & $30 \%$ & $42 \%$ & $28 \%$ & $100 \%$ & & \\
\hline & $501-700$ & $31 \%$ & $37 \%$ & $32 \%$ & $100 \%$ & & \\
\hline & $701-1000$ & $25 \%$ & $50 \%$ & $25 \%$ & $100 \%$ & & \\
\hline & Üle 1000 & $14 \%$ & $44 \%$ & $42 \%$ & $100 \%$ & & \\
\hline \multirow{4}{*}{$\begin{array}{l}\text { Põhikooli- } \\
\text { järgsete } \\
\text { õpperühmade } \\
\text { õpetamine } \\
d f=6\end{array}$} & Ainult neid & $26 \%$ & $34 \%$ & $40 \%$ & $100 \%$ & \multirow{4}{*}{25,63} & \multirow{4}{*}{0,00} \\
\hline & Üle poole & $18 \%$ & $52 \%$ & $30 \%$ & $100 \%$ & & \\
\hline & Alla poole & $29 \%$ & $38 \%$ & $33 \%$ & $100 \%$ & & \\
\hline & Ei õpeta & $39 \%$ & $49 \%$ & $12 \%$ & $100 \%$ & & \\
\hline
\end{tabular}

\section{Kutseõpetajate omistatud tähendused õpilaskonnas toimunud muutustele}

Õpilaskonnas toimuvaid muutusi on kutseõpetajad oma töös kõige tähenduslikumaks pidanud. Võrreldes töökarjääri algusajaga, mis paljudel intervjueeritud kutseõpetajatel ulatub nõukogude perioodi või taasiseseisvumisaja algusesse, nähakse tänapäeva nooremaid õppijaid sageli vähem motiveerituna, halvemate põhiteadmiste, nõrgemate üldoskuste ja tööeetikaga. Samuti kordusid intervjuudes mured õppijate psühholoogiliste ja sotsiaalsete probleemide pärast.

Järgnevalt esitame kvalitatiivse analüüsi tulemused teemade kaupa, avades tähendusi, mille kutseõpetajad omistavad õpilaskonna muutustele.

\section{Õpilaste heaolu}

Võrreldes praegust endiste aegadega, täheldasid kutseõpetajad, et õppijate sotsiaalne heaolu on halvenenud. Nende hinnangul tuleneb see perede vähesest toest. Selline olukord nõuab kutseõpetajatelt professionaalse käitumise muutmist. Kutseõpetajad kirjeldasid emotsionaalselt ja detailselt oma kasvavat kohustust õppijate toetamisel ning vastutust nende elude kujundamise eest. Meenutades oma töökarjäri algusaegu, leidsid kutseõpetajad, et lapsevanemate kasvatuslikud ülesanded on nüüd üha enam neile delegeeritud. Samas on kutseõpetajate võim lahendada vähe distsiplineeritud õpilastega seotud kriitilisi vahejuhtumeid piiratud. 
Mismoodi ma teda karistan, kui ta tundi hilineb? Ma ei tohi teda koridori jätta, siis ta läheb ju üldse minema. Vene ajal, kurat, ma rivistasin üles - teab, et hilines! Nüüd on see nii, et mina olen õigel ajal kohal, aga keda pole? Pole poisse! (Tarmo, staaž 30 a)

Kutseõpetajate mälestustes toimis nõukogude võim vanemaid sanktsioneerivana. Õppijaga tekkinud probleemidest teavitati vanemate töökohti, mis sundis vanemaid võtma vastutust oma laste kasvatamise eest, kuna töökohtade kaudu jagati selliseid privileege nagu telefoniteenus, auto või korteri järjekord. Nüüd tunnevad kutseõpetajad survet muuta oma professionaalset käitumist, kuid kuna võimalused mõjutada õpilaste käitumist on piiratud, tunnevad nad sageli sisemist vastuseisu.

Andmete analüüsist ilmnesid kutseõpetajate nostalgilised mälestused endistest lihtsamatest aegadest. Neid kõrvutati tänapäeva olukorraga, mida iseloomustavad tööränne, lagunenud perekonnad ja laste varajane iseseisvumine. Tulemustest avaldus kutseõpetajate mure selle üle, et tänapäeval tunnevad vanemad vähem huvi oma lapse käekäigu ja õpingute vastu - kutseõpetajate hinnangul on see ülesanne delegeeritud nüüd koolile ja neile. Murrangulise sündmusena rõhutati Nõukogude Liidu lagunemist ja avanenud piiridega kaasnenud töörännet, mis avaldasid mõju peresuhetele ning sedakaudu ka õppijate oskustele. Kutseõpetajate töös on see toonud kaasa vajaduse kujundada õpilaste igapäevaoskusi.

Muudatusi on palju tulnud, kui vana ENSV purunes ja see Eesti Vabariik tuli. Neid lahutusi ja lõhkiseid perekondi on nii palju, siis ei ole lihtsalt seda mehe kätt seal peres ja poisid tulevad siia, et osa poisid on niimoodi, et õpeta kruvi keerama augu sisse. See on ikka üle mõistuse. (Raul, staaž 34 a)

Perekonna toe vähenemise tõttu on kutseõpetajad enda puhul täheldanud kasvavat sotsiaaltöötaja rolli. Kuigi kutseõppeasutustes toimivad tugistruktuurid, kuhu kuuluvad sotsiaalpedagoogid ja psühholoogid, tajuvad kutseõpetajad, et võrreldes töökarjääri algusega nõuavad õpetamisega otseselt mitteseotud ülesanded neil üha rohkem aega ja energiat. Kutseõpetajad kogevad uusi rolliootusi erinevalt. Osas kutseõpetajates põhjustavad emotsionaalset rahulolematust suurenenud ootused töörollidele ja kohustustele panustada üha rohkem kasvatustöösse, teised aga konstrueerivad oma identiteeti „hoolivast õpetajast“, kelle ülesanne kutseoskuste õpetamise kõrval on toetada noorte eluteed tervikuna, pakkudes neile sotsiaalset heaolu. 
See õpilase tohutu üksindus oma probleemidega. Jõuad nendega kuidagi ühele soonele ja ta hakkab äkki sinuga rääkima ja sealt kooruvad välja, et tal ei olegi kellegagi rääkida. Ta suhtlebki ainult omavanustega, et ema ei räägi temaga, isa ei räägi, vanaemadel ka ei ole aega ... Sa oledki ainuke vanema põlvkonna esindaja, kellega tal on rääkida ja suhelda ja arutada. Et see on nagu kurb minu meelest. Kõigil on ju kiire ja vanemad ei saa aru. (Tiina, staaž 25 a)

Analüüsist ilmnesid kutseõpetajate juhtumid õppijatega (eriti noormeestega), kelle perede keeruline olukord on mõjutanud nende psüühikat. Kuna kutseõpetajatel on raske nendeni jõuda, ei saa nad neid ka aidata.

Need poisid on kuidagi kinnised, ütleme nagu oma sisse kapseldunud. Nendesse on väga raske sisse tungida. Neil on ikkagi see oma pere ja kõik see omapoolne osa ikka nii palju liimist lahti ja poisil ei ole kuskile poole pöörduda. Võib-olla ta mõtleb ka seda, et aga mis see õpetaja siin koolis saab teha. Nad on psüühiliselt haiged, kõik see mõtlemise laad on hoopis teine, suhtumine. (Raul, staaž 34 a)

Laienenud töörollid panevad kutseõpetajate professionaalses tegevuses proovile nende sotsiaalpedagoogilise ja psühholoogilise pädevuse.

\section{Õpilaste suhtumine õppimisse}

Tulemustest selgus, et kutseõpetajad on oma karjääri jooksul kogenud mitmesuguseid tähenduslikke sündmusi, mis peegeldavad õpilaste vähenenud motivatsiooni, vastutus- ja kohusetunnet ning suhtumist õppimisse, mis omakorda on mõjutanud nende professionaalset käitumist.

Kutseõpetajate nostalgilised mälestused oma karjääri algusest seostuvad motiveeritud õpilastega, kelle erialavalik oli teadlikum, mistõttu olid nad pühendunud õpingutele ning väljalangemus oli väiksem. Kutseõpetajad on täheldanud praeguste noorukiealiste õpilaste vähest entusiasmi või huvi õpitava valdkonna vastu. Muutused õpilaste motivatsioonis tähendavad kutseõpetajate professionaalses tegevuses vajadust muuta õppeprotsessi huvitavamaks ning oma eeskujuga tugevdada õpilaste sisemist motivatsiooni. Püüdlustest hoolimata on kutseõpetajad tajunud, kuidas õpilaste ükskõikne suhtumine õppimisse häirib nende igapäevatööd, põhjustades negatiivseid emotsioone ja vähendades nende soovi kutseõpetajana töötada.

Kõige rohkem seda motivatsiooni mõjutab just see õpilaste suhtumine, et millal sa saad seda positiivsust? Aga pidevalt on see, ei esitata töid, ei käida kohal, hindeid ei saa välja panna. Miks on niimoodi? Kui sa näed ka sära silmis, siis tahaks ka õpetada. (Kaire, staaž 23 a) 
Vastukaaluks negatiivsele pakuvad täiskasvanud õppijad kutseõpetajatele valdavalt positiivseid emotsioone. Täiskasvanud õppijad, kelle osakaal õpilaskonnas on suurenenud, on teadlikumad oma kutsevalikutest, motiveeritumad ja ópihimulisemad. Nende ootused erialaste teadmiste ja oskuste suhtes on suuremad, nõudes kutseõpetajatelt õppesisu valdamist väga heal tasemel.

Need, kes on juba vanemad, need tulevad täie teadmisega ja nad teavad, mis nad tahavad. Ja vaata, nende ootused ja nõudmised on ikka palju suuremad. Et see õpetaja, kes seal annab, ta peab ikka olema kõigega kursis, et ta saab anda neile kõik, mis nad tahavad. (Pille, staaž 39 a)

Analüüsist ilmnesid positiivsed meenutused nn vana aja õpilaste tõsisest töösse suhtumisest, mida kujundati nii kodus kui ka koolis. Tänapäeva noorukite viletsamat suhtumist ning puuduvat vastutus- ja kohusetunnet põhjendatakse heaoluühiskonnaga ja peretoe puudumisega.

Eriti kurvastav on see, et koolid ei õpeta õpilast töötama, et pannakse nagu pahaks, et ole korrapidaja. Töövaenulik suhtumine. Kui koolis seda ei õpetata, siis ei tule seda kuskilt. Kui ta loobib paberi maha, viskab vastu seina või sigatseb, see on oluliselt kasvanud. See näitab ka seda, et kodus ei ole temaga vanematel aega olnud tööd teha. (Aivar, staaž 47 a)

Mõeldes noorukite muutunud suhtumisele, väljendasid kutseõpetajad igatsust sellise aja järele, mil ühiskonnas väärtustati tööd ja tööga seotud väärtusi kandsid nii kodud, haridusasutused kui ka töökohad. See lihtsustas nende jaoks õppe- ja kasvatustööd. Kutseõpetajate praegused kogemused seostuvad pigem negatiivsete emotsioonidega - vajadusega tulla toime selliste raskustega nagu õpilaste motiveerimine, vastutus- ja kohusetunde kasvatamine.

\section{Õpilaste üldine õpioskus}

Analüüsist selgub, et võrreldes varem kogetuga on tänapäeva noorukitel rohkem raskusi keskendumisega ja probleeme õpioskustega, mistõttu tuleb kutseõpetajatel oma professionaalses tegevuses rohkem tähelepanu pöörata teoreetiliste teemade selgitamisele ja individuaalsele lähenemisele praktiliste oskuste õpetamisel.

Õpilastel on raskusi süvenemisega. Tunnis seda selgitustööd ja praktikal ka, seda individuaalset tööd on tulnud tunduvalt rohkem juurde kui aastaid varem. Õpilastel järjest raskem omandada seda, mis on kirjapildis. (Tiina, staaž 25 a) 
Kutseõpetajatel on ette tulnud olukordi, kus noorukid ei suuda oma puudulike õpioskuste tõttu planeerida õppimist ega suunata tähelepanu olulisematele tegevustele.

Praegu on nii, et nad ei hakka enne vaatamagi, kui tähtaeg on möödas ja võlgnevused tulevad. Aga need, kes on laisemad või ei oska planeerida aega, nende jaoks on see lõpp ikka ränk. Neid asju tuleb nii palju, mis korraga peaks saama. 15 aastat tagasi ei olnudki seda. Praegu ma peaksin neid aitama peale tunde. (Liina, staaž 31 a)

Sellised muutused õpilastes toovad kutseõpetajatele kaasa planeerimata tööd, mis tihti kuhjub, samuti peavad nad pöörama suuremat tähelepanu õpilaste õpioskuste toetamisele. Samas täiskasvanud õppijad, kes planeerivad oma õppimist muude kohustuste kõrvalt ning tulevad õpingutega ennastjuhtivalt toime, ootavad paindlikkust õppeprotsessis, et tööd ja õppimist ühitada.

Kutseõpetajad on kogenud õpilaskonna mitmekesistumisega seotud raskusi, sest täiskasvanud õppijad erinevad üksteisest vanuse, varasema hariduse ja kogemuste poolest. See avaldab mõju õppijate õpikiirusele ja nõuab kutseõpetajatelt oskuslikkust õppetöö diferentseerimisel.

Viiekümne kolme aastane ei haara nii kiiresti seda, mis noorem haarab. Õpetaja peab siis olema valmis ka selliseks olukorraks, kui olen tunnis, noorem sai juba kõigest aru, ta tegi selle töö ära, aga vanem vajab veel selgitust ja seletust ja abi. See teeb selle asja et natukene keerulisemaks, et nüüd see noorem, kes mul on tunnis, ei hakka igavlema, et te tegelete selle vanemaga. Just see vanusevahe, see, kui kiiresti nad midagi haaravad või aru saavad. (Pille, staaž 39 a)

Muutus õpilaste toimetulekus õppimisega tähendab kutseõpetajatele pidevalt oma töö ümberplaneerimist ning paindlike ja diferentseeritud õppimisvõimaluste loomist, et arvestada nii noorukite kui ka täiskasvanute õpioskuste ja -vajadustega.

\section{Õpilaste põhiteadmised ja -oskused}

Analüüsist selgus, et aasta-aastalt on põhikoolijärgsete õpilaste põhiteadmiste ja -oskuste tase halvenenud, mistõttu ollakse mures põhihariduse üldise kvaliteedi pärast. Professionaalses tegevuses tähendab see kutseõpetajatele vajadust õpetada põhikoolis omandamata jäänud põhiteadmisi ja -oskusi, kuna need on eelduseks kutsepädevuste omandamisele. 
Millega nad [õpilased] üldharidusest välja saadetakse, see on väga nõrk. Sest meie ei näe neid tugevamaid. Üldhariduses istuma ei jäeta, selle kolme väärtus - mul ei tea pool rühma korrutustabelit peast. (Tarmo, staaž 30 a)

Näiteks tisleri eriala kutseõpetaja meenutab nostalgiliselt aegu, mil põhikoolist tulid erialale õppima heade ja väga heade teadmiste ning oskustega õpilased. Nüüd on paljudel õpilastel raskusi lihtsamate matemaatiliste tehete sooritamisega. Kuna õpilaste põhiteadmiste tase on erinev, siis tähendab see taas kord kutseõpetajatele vajadust diferentseerida õpet ja arendada selleks vajalikke ametialaseid teadmisi.

Kui mina kaheksakümnendatel alustasin, siis oli järjekord tislerite erialale. Siis me saime neljalisi-viielisi valida, kolmelised ärgu üldse tulgugi. Aga nüüd on niimoodi, et me võtame kõik vastu. Ühel mehel tase on, et on raskusi 42 kolmeks jagada, ja teine mees jagab seal 423 kolmeks peast. Et sinna läheb jälle nii palju auru, selle kahe erineva õpilase vahele. (Raul, staaž 34 a)

Eeltoodule lisaks on täheldatud noorte lugemisharjumuse teisenemist ja funktsionaalse lugemisoskuse halvenemist, mis nõuab kutseõpetajatelt professionaalsust õpetada kutse- ja võtmepädevusi lõimituna.

Lugemisoskus, arusaamise oskus, see on nagu taandarenenud. Ma spetsiaalselt teen nendele lugemise treeningut. Neljandal kursusel ta juba hakkab aru saama, mis seal raamatus kirjas on. (Mirjam, staaž 29 a)

Oma karjääri jooksul on kutseõpetajad märganud, et õppijate suhtlemisoskus on halvenenud, seostades seda nutiseadmete kasutamise negatiivse mõjuga. Kutseõpetajad on olnud olukorras, kus nutikeskkondadega harjunud noored kardavad näost näkku suhelda. Kutseõpetajad tunnevad kasvavat vastutust noorte suhtlemisoskuse arendamisel, et tagada õpilaste valmisolek suhelda ettevõttepraktikal kolleegidega.

Sa lihtsalt tunnis ei jäta neid rahule, nüüd sa rägigi sellega, nüüd minuga, nüüd räägime kõik koos. See tähendab nüüd, ma olen tähele pannud, et seda peab rohkem tegema. (Mirjam, staaž 29 a)

Analüüsist selgus, et kutseõpetajad mäletavad oma karjääri alguses olnud õpilasi, kes olid võimekamad. Uued olukorrad on tekitanud aga vajaduse pöörata õpilaste põhiteadmiste ja üldoskuste arendamisele suuremat tähelepanu, eeldades kutseõpetajatelt muutunud professionaalsust. 


\section{Õpilaste tolerantsus ja omavaheline läbisaamine}

Analüüsist selguvad kutseõpetajate vastandlikud kogemused, mis on seotud õpilaste tolerantsuse ja omavahelise läbisaamisega. Üks kutseõpetaja kirjeldas olukorda, kus tema kooli õpilased on muutunud varasemate õpilastega võrreldes tolerantsemaks ja tähelepanelikumaks erivajaduste ja sotsiaalsete probleemidega kaasõpilaste suhtes ning olnud sellega eeskujuks ka õpetajatele. Lisaks on kutseõpetaja hinnangul jäänud tunduvalt vähemaks omavahelist kiusamist. Seevastu teine kutseõpetaja peab iga õppeaasta alguses nägema uue õpperühmaga vaeva, et õpilased oleksid üksteise vastu sallivamad.

Ma tean seda oma kooli põhjal, siis on see omavaheline sallimatus, kui keegi on teistmoodi. Iga jumala aasta pean tegelema sellega, et jätke rahule inimesed, kõik ei pea olema ühtemoodi. Seda on nagu rohkem, millega sa pead tegelema, sellist sallimatust, see on nagu esimestel noorematel kursustel (Mirjam, staaž 29 a)

Tulemustest võib näha, et kutseõpetajad mõtestavad õpilaste tolerantsuse muutumist erinevalt, lähtudes kogetud olukordadest. See aga nõuab erinevat professionaalset tegevust.

\section{Õpilaste aktiivsus ja ettevõtlikkus}

Analüüsist ilmnes, et kutseõpetajatel on õppijate aktiivsuse ja ettevõtlikkusega erinevaid kogemusi. Oma karjääri vältel on nad täheldanud, et heaoluühiskond on suurendanud noorukite mugavust, laiskust ja passiivsust. See muutus paneb taas kord proovile kutseõpetajate professionaalse tegevuse, nõudes neilt oskusi kaasata sobivate aktiivõppemeetodite kaudu õpilasi tõhusamalt õppeprotsessi ja nõudes neilt selleks paremat ettevalmistust.

Õpilane on muutunud mugavamaks, elu on paremaks läinud. Kooli tasandil töö lihtsalt raskemaks läinud, sest mugavustsoonist tulnud ópilane, temaga on raskem töötada, õpetaja peaks olema paremini ettevalmistanud. (Aivar, staaž 47 a)

Täiskasvanud õppijate puhul on kutseõpetajad täheldanud aktiivsuse ja ettevõtlikkuse varieerumist. Näiteks on olnud juhtumeid, kus aktiivne õpilane lahkus õpperühmast kaasõppijate passiivsuse tõttu või üksikutel ettevõtlikel õppijatel on vähesel määral õnnestunud kaasõppijaid tegevustesse kaasata. Kutseõpetaja on põhjendanud täiskasvanud õppijate vähest kodanikuaktiivsust õppimisele pühendumisega. 


\begin{abstract}
Alati on meil selliseid liidreid, kes hakkab siis organiseerima. No kes siis tuleb kaasa, no tegelikult ikka tulevad kaasa. Kuigi kui ei tule kaasa, siis juba ei tule kaasa. Ja üks tüdruk on väga tugev isiksus, selline liider, tema siis tahtis igal pool käia. Aga grupp ei läinud kaasa. Sellepärast, et on õppida ja on iseseisvat tööd kõike teha. (Varje, staaž 38 a)
\end{abstract}

Seega on kutseõpetajate kogemuste põhjal õppijate aktiivsus ja ettevõtlikkus pigem vähenenud, kuid selle põhjused on erinevad.

\title{
Kokkuvõte ja järeldused
}

Uurimuse eesmärk on selgitada kutseõpetajate kogetud muutusi õpilaskonnas, tuginedes professionaalse mälu kontseptsioonile. Keskendutud on õpetajate professionaalset mälu iseloomustavatele karakteristikutele, nagu vanus ja tööstaaž, tähendusrikastele sündmustele ning emotsionaalsetele ja nostalgilistele mälestustele. Uurimistulemustest selgus, et kutseõpetajate kogetud muutused õpilaskonnas on mitmekesised. Statistiliselt eristuvad nende kutseõpetajate klastrid, kellel on pigem kas positiivsed, varieeruvad või negatiivsed kogemused.

Seostades kutseõpetajate kogemusi professionaalse mälu karakteristikutega, selgus, et väiksema pedagoogilise kogemusega ja nooremad kutseõpetajad hindavad õpilaskonna muutusi positiivsemalt. See on kooskõlas Hargreavesi (2005) professionaalse mälu kujunemise käsitlusega, mille kohaselt suhtuvad vähese töökogemusega õpetajad muutustesse positiivsemalt, kuna neil puuduvad varasemad kogemused, millega olemasolevat olukorda võrrelda. Kuigi Hargreavesi pedagoogiliste kogemuste etappide alusel suhtuvad 20-aastase ja suurema pedagoogilise kogemusega õpetajad muutustesse negatiivsemalt, siis meie uurimistulemused õpilaskonna muutuste kontekstis seda ei kinnita. Staažikate kutseõpetajate hinnangud õpilaskonna muutustele on hoopiski varieeruvad.

Kõrvutades kutseõpetajate täheldatud muutusi teiste demograafiliste ja kooli teguritega, ilmnes, et need seostuvad õpilaste arvuga koolis ning õpperühmadega. Kutseõpetajatel, kes õpetasid suuremates koolides ja põhikoolijärgseid õpperühmi, on õpilaskonna muutustega seoses negatiivsemad kogemused. Selle põhjal võib öelda, et peamised muret tekitavad muutused õpilaskonnas seostuvad kutseõpetajatel pigem noorukiealiste õppijatega, mis selgus ka staažikate õpetajate intervjuudest. Vastukaaluks probleemsetele noorukitele pakuvad täiskasvanud õppijad kutseõpetajatele rõõmu ja rahuldust, sest nende ootused õppimisele ja õpetamisele on üldjuhul suuremad, nõudes kutseõpetajatelt paindlikkust professionaalses tegevuses. Seda tulemust 
kinnitavad ka teiste riikide kutseõpetajate positiivsed kogemused (Cort, 2010; Hughes \& Attwell, 2010).

Kutseõpetajate professionaalsed mälestused on põimunud erinevate tähendusrikaste sündmuste/pöördepunktidega, mis on toonud kaasa muutusi õpilaskonnas ja seeläbi mõjutanud kutseõpetajate professionaalset tegevust (Ben-Peretz, 2002). Esiteks, hariduspoliitiline otsus vähendada põhikoolis klassikursuse kordama jätmise praktikat avaldub kutseõpetajate hinnangul noorukite kehvades põhi- ja õpioskustes, see aga toob kaasa vajaduse leida professionaalses tegevuses uusi võimalusi tegelda õppijate puudulike põhiteadmistega. Samas ei seosta kutseõpetajad ise õpilaste nõrgenenud põhiteadmisi ja -oskusi kutsehariduspoliitiliste prioriteetidega, mis on tekitanud olukorra, kus kutseõppesse kaasatakse akadeemiliselt vähem võimekaid noori, et pakkuda neile võimalusi osaleda ühiskonnas ja tööelus (Eesti kutseharidussüsteemi arengukava, 2009; Loogma, 2013; Ümarik \& Rekkor, 2013). Õppijate vähenenud huvi õpitava eriala vastu ja motivatsiooniprobleeme põhjendavad kutseõpetajad peamiselt vale erialavalikuga, mida varasemates uurimustes on seostatud nõukogudeaegse karjäärinõustamissüsteemi kaotamisega (Sirk et al., 2016) - sedagi võib käsitleda ühe hariduspoliitilise võtmesündmusena.

Nõukogude Liidu lagunemisele järgnenud sotsiaalsed ja tööturumuutused on olnud kutseõpetajate professionaalse mälu seisukohalt tähendusrikkad, seostudes noorukite suurenenud probleemidega, nagu näiteks sagenenud psüühilised probleemid, laiskus ja passiivsus. Varasemate kogemuste ja nostalgiliste mälestuste taustal on kutseõpetajad kriitiliselt hinnanud praeguste õpilaste töödistsipliini ja töökasvatuse puudumist, millele on viidanud ka tööandjad (Nestor \& Nurmela, 2013). Üldine heaolu kasv, perekonna tähenduse, aga ka inimeste eluviiside muutus on vähendanud osas peredes vanemate vastutust lapse kasvatamise eest. See omakorda tekitab kutseõpetajate professionaalses tegevuses eetilise dilemma, kuivõrd peab nende roll sisaldama hoolivust ja vastutust õppijate käekäigu eest, st kas nad peaksid täitma justkui sotsiaaltöötaja rolli, pakkudes õppijatele puuduvat peretuge. Uute rollide aktsepteerimine suurendab muu hulgas kutseõpetajate töökoormust. Kuigi meie kutseõpetajad seostavad õpilaskonna muutusi paljuski ühiskondlike protsesside ja elustiilide muutustega, mis olid tingitud Eesti üleminekuajast, on sarnastele raskustele kutseõpetajate tööelus viidatud ka teiste riikide uurimustes (nt Cort \& Rolls, 2010; Hughes \& Attwell, 2010; Kats et al., 2010; Kirpal, 2011; Susimetsä, 2010).

Probleemsete õppijate vastandamine motiveeritumatele ja võimekamatele noortele ning nn vana aja õppijatega seotud nostalgia ja positiivsed emotsioonid kerkisid kutseõpetajate professionaalsetes mälestustes korduvalt esile. Samale tendentsile on viidanud ka varasemad uurimused (Ümarik \& Goodson, 
2018). Nn vanade heade õppijate rõhutamine kollektiivselt konstrueeritud arusaamades peegeldab kutseõpetajate professionaalset mälu ning aitab mõtestada nende praegust tööd ja muutunud rolle (Ben-Peretz, 2002; Goodson et al., 2006; Tarpey, 2015, 2016).

Tulemuste tõlgendamisel tuleb arvestada asjaolu, et kvalitatiivne andmestik võimaldas avada õpilaskonna muutustele antud tähendusi ainult staažikate kutseõpetajate kogemuste kaudu, mida võib käsitleda piiranguna, kuna avamata jäid väiksema pedagoogilise kogemusega kutseõpetajate antud tähendused. Seetõttu tuleks järgmistes uurimustes suuremat tähelepanu pöörata eri tööstaažiga intervjueeritavate kogemustele. Kuna küsitluse tulemustest selgus, et kutseõpetajad tööstaažiga 6-19 aastat hindavad õpilaskonna muutusi kõige negatiivsemalt, siis oleks oluline mõista tegureid, mis kujundavad selle kutseõpetajate rühma hoiakuid.

Kokkuvõtvalt võib öelda, kutseõpetajate professionaalse mälu roll õppijatega seotud kogemustes on kompleksne, sõltudes ühiskondlikest ja hariduspoliitilistest muutustest ning kutseõpetajate kogemustest ja töö kontekstist. Pedagoogilise karjääri alguses olevad kutseõpetajad hindavad õpilaskonnas toimunud muutusi positiivsemalt, kuna neil puuduvad mälestused nn vana aja õppijatest, mis mõjutaks nende kogemusi. Samas staažikamatel kutseõpetajatel, kes õpetavad eri vanuses õppijaid, on varieeruvad kogemused. Kuigi kutseõppes on täiskasvanud õppijate osakaal kasvanud ja nendega on kutseõpetajatel positiivsemad kogemused, siis kaldutakse pigem rõhutama noorukitega seotud negatiivsemaid kogemusi. Seeläbi taastoodetakse kutsehariduse nõrga ja probleemse õpilaskonna diskursust, mis mõjub kutsehariduse kuvandile ühiskonnas pigem negatiivselt. Professionaalse mälu kontseptsiooni põhjal võib järeldada, et negatiivsed muutused seostuvad selliste kriitiliste sündmuste/intsidentidega, mis esitavad kutseõpetajate tööle uusi väljakutseid, millega võib olla raske kohaneda. Ühelt poolt on näha, et professionaalne mälu võib takistada muutustega kohanemist, sest konstrueeritakse võrdluspilte vanadest headest aegadest. Teisalt on professionaalsel mälul muutuste kontekstis positiivne funktsioon, sest see võimaldab tänapäeva õpetajatööd kriitiliselt mineviku valguses reflekteerida (Ben-Peretz, 2002; Tarpey, 2009) ja haridusmuutusi hinnata.

Seega peaks enam teadvustama kutseõpetajate professionaalse mälu ja nostalgiliste mälestuste kahepidist rolli muutustega (sh õpilaskonnas toimuvate muutustega) kohanemisel. Staažikate kutseõpetajate professionaalne areng vajab senisest suuremat toetust, mis aitaks neil näha oma professionaalse mälu potentsiaali. Ühtlasi võimaldab see neil märgata positiivseid muutusi ning saada paremini hakkama neile muret valmistavate tendentsidega õpilaskonnas. 


\section{Tänusõnad}

Artikkel on valminud IUT18-2 teadusteema „Õpetajate professionaalsuse ja professionalismi muutuv kontekst (01.01.2014-31.12.2019)“ raames, mida rahastab sihtasutus Eesti Teadusagentuur.

Täname kõiki kutseõpetajaid, kes nõustusid uuringutes osalema.

\section{Kasutatud kirjandus}

Braun, V., \& Clarke, V. (2006). Using thematic analysis in psychology. Qualitative Research in Psychology, 3(2), 77-101. https://doi.org/10.1191/1478088706qp063oa

Ben-Peretz, M. (2002). Retired teachers reflect on learning from experience. Teachers and Teaching, 8(3/4), 313-323. https://doi.org/10.1080/135406002100000468

Cedefop (2017). Eesti kutseharidus: lühiülevaade. Luxembourg: Euroopa Liidu väljaannete talitus.

Cort, P. (2010). Synthesis of findings on CVET teachers and trainers. In S. Kirpal (Ed.), Changing roles and competences of VET teachers and trainers. Final Report I Vol. II: National summaries of interview results (pp. 55-58). Bremen: University of Bremen.

Cort, P., \& Rolls, S. (2010). IVET teachers' perceptions of change and their implications for teaching. In S. Kirpal (Ed.), Changing roles and competences of VET teachers and trainers. Final Report / Vol. II: National summaries of interview results (pp. 59-69). Bremen: University of Bremen.

Creswell, J. W. (2010). Mapping the developing landscape of mixed methods research. In A. Tashakkori \& C. Teddlie (Eds.), Sage handbook of mixed methods in social \& behavioural research (2nd ed., pp. 46-67). California: Sage Publication. https://doi.org/10.4135/9781506335193.n2

Creswell, J. W. (2012). Educational research: Planning, conducting, and evaluating quantitative and qualitative research. Boston: Pearson Education.

Cunningham, P. (2007). Plowden in history: Popular and professional memory. Forum, 49(1/2), 22-31. https://doi.org/10.2304/forum.2007.49.1.21

Eesti elukestva õppe strateegia 2020 (2014). Tartu: Haridus- ja Teadusministeerium. Külastatud aadressil https://www.hm.ee/sites/default/files/strateegia2020.pdf.

Eesti kutseharidussüsteemi arengukava aastateks 2005-2008 (2005). Tartu: Haridus- ja Teadusministeerium.

Eesti kutseharidussüsteemi arengukava 2009-2013 (2009). Tartu: Haridus- ja Teadusministeerium. Külastatud aadressil https://www.hm.ee/sites/default/files/kutse haridusysteemi_arengukava_2009_2013.pdf.

Espenberg, K., Beilmann, M., Rahnu, M., Reincke, E., \& Themas, E. (2012). Oppingute katkestamise põhjused kutseõppes. Tartu: Tartu Ülikooli sotsiaalteaduslike rakendusuuringute keskus RAKE ja CPD OÜ.

Gardner, P. (2003). Oral history in education: Teacher's memory and teachers' history. History of Education, 32(2), 175-188. https://doi.org/10.1080/00467600304159

Goodson, I. (2003). Professional knowledge, professional lives: Studies in education and change. Maidenhead: Open University Press. 
Goodson, I., Moore, S., \& Hargreaves, A. (2006). Teacher nostalgia and the sustainability of reform: The generation and degeneration of teachers' missions, memory, and meaning. Educational Administration Quarterly, 42(1), 42-61.

https://doi.org/10.1177/0013161X05278180

Hargreaves, A. (2005). Educational change takes ages: Life, career and generational factors in teachers' emotional responses to educational change. Teaching and Teacher Education, 21(8), 967-983. https://doi.org/10.1016/j.tate.2005.06.007

Haridussilm (2018). Haridus: statistika. Külastatud aadressil https://www.haridussilm.ee/.

Hughes, J., \& Attwell, G. (2010). Training needs of trainers and VET teachers in the UK. In S. Kirpal (Ed.), Changing roles and competences of VET teachers and trainers. Final Report / Vol. II: National summaries of interview results (pp. 7-22). Bremen: University of Bremen.

Kats, E., van Lakerveld, J., \& Smit, H. (2010). Changing roles and competences in vocational training and professional development - Reflections on the interviews with Dutch educational professionals. In S. Kirpal (Ed.), Changing roles and competences of VET teachers and trainers. Final Report / Vol. II: National summaries of interview results (pp. 23-33). Bremen: University of Bremen.

Kirpal, S. (2011). Emerging roles and competence requirements of teaching and training practitioners - A European perspective. In S. Kirpal (Ed.), National pathways and European dimensions of trainers' professional development (pp. 27-44). Frankfurt am Main: Peter Lang.

Kutseharidusprogramm 2018-2021 (2018). Tartu: Haridus- ja Teadusministeerium. Külastatud aadressil https://www.hm.ee/sites/default/files/7_kutseharidusprogramm_2018-2021.pdf.

Loogma, K. (2013). Kutseharidus. R. Mikser (toim), Haridusleksikon (lk 162-169). Tallinn: Eesti Keele Sihtasutus.

Mason, J. (2002). Qualitative researching. London: Sage Publications.

Nestor, M., \& Nurmela, K. (2013). Kutseharidus ja muutuv tööturg. Tööandjate uuringu lõpparuanne. Tallinn: Poliitikauuringute Keskus Praxis.

Rekkor, R., Ümarik, M., \& Loogma, K. (2013). Adoption of national curricula by vocational teachers in Estonia. Journal of Vocational Education and Training, 65(4), 489-506. https://doi.org/10.1080/13636820.2013.841277

Riigikontroll (2016). Ülevaade täiskasvanute osalemisest kutseõppes. Külastatud aadressil http://www.riigikontroll.ee/tabid/206/Audit/2375/Area/1/language/ et-EE/Default.aspx.

Sirk, M., Liivik, R., \& Loogma, K. (2016). Changes in the professionality of vocational teachers as viewed through the experiences of long-serving vocational teachers in Estonia. Empirical Research in Vocational Education and Training, 8(13), 1-26. https://doi.org/10.1186/s40461-016-0039-7

Statistikaamet (2007). Kutseharidus 1996-2006. Tallinn: Statistikaamet.

Susimetsä, M. (2010). Finland. In S. Kirpal (Ed.), Changing roles and competences of VET teachers and trainers. Final Report / Vol. II: National summaries of interview results (pp. 71-78). Bremen: University of Bremen.

Tafel-Viia, K., Loogma, K., Lassur, S., \& Roosipõld, A. (2012). Networks as agents of innovation: Teacher networking in the context of vocational and professional higher education reforms. Vocations and Learning, 5(2), 175-193.

https://doi.org/10.1007/s12186-012-9077-x 
Tamm, A. (2011). Riiklike õppekavade rakendumine kutseõppeasutustes. Tallinn: Klaris. Tarpey, P. (2009). Professional memory and English teaching. English Teaching: Practice and Critique, 8(1), 52-63.

Tarpey, P. (2015). Professional memory in context: Can it help counter the 'counterrevolution'? Changing English, 22(4), 382-392. https://doi.org/10.1080/1358684X.2015.1109836

Tarpey, P. (2016). Fire burn and cauldron bubble: What are the conjunctural effects on English teacher professional memories, identities and narratives? Changing English, 23(1), 77-93. https://doi.org/10.1080/1358684X.2015.1133767

Tegevuskava kutseharidussüsteemi arendamiseks Eestis aastatel 2001-2004 (2001). Tallinn: Haridusministeerium, Kutsehariduse ja Tööhõive Seirekeskus.

Van Middelkoop, D., Ballafkih, H., \& Meerman, M. (2017). Understanding diversity: A Dutch case study on teachers' attitudes towards their diverse student population. Empirical Research in Vocational Education and Training, 9(1), 1-19. https://doi.org/10.1186/s40461-016-0045-9

Vähäsantanen, K., \& Eteläpelto, A. (2011). Vocational teachers' pathways in the course of a curriculum reform. Journal of Curriculum Studies, 43(3), 291-312. https://doi.org/10.1080/00220272.2011.557839

Ümarik, M., \& Goodson, I. F. (2018). Nostalgia in the narratives of vocational teachers as a way of understanding responses to change. Critical Studies in Education. https://doi.org/10.1080/17508487.2018.1500385

Ümarik, M., \& Rekkor, S. (2013). Diversification of students and professional roles of vocational teachers: Teachers' individual approaches to negotiate work identities. In J. Mikk, M. Veisson, \& P. Luik (Eds.), Change in teaching and learning, 5 (pp. 9-26). Frankfurt am Main: Peter Lang. 


\title{
How professional memory influences vocational teachers' perception of changes related to students
}

\author{
Meidi Sirk $^{\text {al }}$, Reeli Liivik ${ }^{\mathrm{a}}$, Meril Ümarik ${ }^{\mathrm{a}}$, Krista Loogma \\ a School of Educational Sciences, Tallinn University
}

\begin{abstract}
Summary
Global changes and reform policies have affected the work and professionalism of vocational teachers. The qualification requirements for vocational teachers have risen and their work roles have widened. The teacher has been regarded as being responsible for the quality of graduates entering into the workplace (Sirk et al., 2016). Among various changes in vocational teachers' work, student related changes have been perceived as the most challenging ones shaping their everyday working lives (Sirk et al., 2016; van Middelkoop et al., 2017). Students' learning difficulties and behavioural problems, lack of motivation and support from the families have broadened the work roles of vocational teachers and added new roles, such as social worker, mentor and councillor (Cort \& Rolls, 2010; Hughes \& Attwell, 2010; Kats et al., 2010; Sirk et al., 2016; Susimetsä, 2010). All this poses new challenges to vocational teachers' psychological and social pedagogical competences (Kirpal, 2011).

Vocational teachers have perceived all these changes in their work differently and hold more or less positive attitudes regarding them. Previous studies have shown that the adoption of changes is related to teachers' personal characteristics, and also their professional approach (Rekkor et al., 2013; Tafel-Viia et al., 2012; Vähäsantanen \& Eteläpelto, 2011; Ümarik \& Rekkor, 2013). However, previous studies do not explain how the perception of the change in the student population is related to the professional experience of vocational teachers.

Hargreaves (2005) has emphasised the importance of how the length of career, experience and age is related to the development of the professional memory (PM). PM builds on memories of emotional experiences or feelings (Ben-Peretz, 2002) and reflects on nostalgia that affects the adaptation to new changes, especially among experienced teachers near to their retirement age (Goodson et al., 2006). PM is also related to teachers' memories of their previous professional practices (Tarpey, 2015) that are associated with emotions and are always socially constructed (Ben-Peretz, 2002; Goodson et al., 2006;
\end{abstract}

School of Educational Sciences, Tallinn University, Narva mnt 25, 10120 Tallinn, Estonia; meidi.sirk@tlu.ee 
Tarpey, 2015, 2016). Teacher's professional memories incorporate collective professional practices, beliefs and professional development. Therefore, memories cannot be isolated, but contextual, belonging to a certain cultural context and period of time (Tarpey, 2009, 2015). The aim of this study is to explain how vocational teachers experience changes within the student population through the concept of PM.

The sequential mixed methods approach has been applied as a methodological design in the study (Creswell, 2010). First, we analysed the quantitative data. We grouped vocational teachers based on the perceptions of the changes in student population by using k-means clustering. The teacher groups formed were compared to PM characteristics (length of pedagogical experiences and age), other demographic characteristics and school context factors. In the next stage, we analysed the qualitative semi-structured interviews of nine vocational teachers, representing different vocational fields, who had 20 years or more teaching experience. The qualitative thematic analysis enabled us to discover what causes vocational teachers have attributed to the changes in the student population.

The quantitative analysis resulted in three different groups of teachers based on their perceptions on student related changes: positive, various and negative. Comparison of groups with PM characteristics (age and length of pedagogical experience) revealed that vocational teachers with lesser pedagogical experiences and younger teachers tend to have more positive experiences related to changes of student population than others. This matches with Hargreaves' (2005) idea that teachers' career phases are related to the development of PM and readiness to adapt to change. In addition, the size of the school and the nature of student groups taught were related to teachers' experiences. Therefore, vocational teachers that perceived students related changes most negatively tended to work in larger schools and teach younger students (those entering VET school after 9th grade). This result confirms that the main problems relate to teaching adolescents. In professional memories of vocational teachers more positive emotions related to the teaching of adult learners emerged that provides work satisfaction but also poses challenges for their professional knowledge and competence.

Results from the qualitative analysis show that experienced vocational teachers had a negative attitude towards student related changes. Nostalgic memories contributed to them comparing today's students with those they taught at the beginning of their career. The changing work roles, professional activities and loss of power of vocational teachers are related to these changes. The problem of today's students having lower motivation and lower basic competence, as compared to those in the past, was emphasised, which suggests a new professional approach and methods are required from vocational 
teachers. It is significant that the low motivation of students also affects the motivation of the vocational teachers. The "good old students" understanding co-constructed by vocational teachers reflects vocational teachers' PM and shapes their work identity and present work roles (Ben-Peretz, 2002; Goodson et al., 2006; Tarpey, 2015, 2016).

The transitional societal context after regaining the independence and joining the EU were highlighted by vocational teachers as a critical period that brought about numerous problems, such a psychological problems, laziness and inactivity. Vocational teachers are faced with a dilemma to accept or refuse the new role as that of social worker and replace the care and support lacking from the families. Moreover, teachers are concerned that at present neither parents nor schools are responsible for developing students' work ethics. Today's society requires us to increase student rights, whilst decreasing teachers' power and authority in the classroom.

Several aspects, such as shifts in the socially acceptable norms, transitional context, educational policies and school context, tend to affect student population and also shape vocational teachers' PM. Teachers who are at an early stage in their career hold more positive attitudes toward the student population, because they do not have nostalgic memories of "old time students" that could affect their experiences. Experienced vocational teachers have both negative and positive experiences related to students. So, the question emerges why vocational teachers encounter more negative experiences? According to PM conception we may conclude that negative changes are challenges for teachers that are hard to cope with. Thus, on one side PM hinders coping with changes because changes are compared with memories. On the other hand, PM enables to reflect changes in teachers' work and education (Ben-Peretz, 2002; Tarpey, 2009). Thus, it is important that we understand the impact of nostalgic memories on vocational teachers professional memory because these might prevent them coping with changes. Accordingly, more attention should be paid to support the professional development of long-serving vocational teachers to notice positive aspects in the student population and educational changes in general.

\section{Acknowledgements}

The article is part of the national research project IUT18-2 "Teachers' professionality and professionalism in changing context (01.01.2014-31.12.2019)", supported by the Estonian Research Council.

Keywords: professional memory, changes in the vocational student population, vocational teachers experiences 